\title{
PENGARUH MODEL EXPERIENTIAL LEARNING BERBANTUAN APLIKASI PHYPHOX TERHADAP MOTIVASI BELAJAR FISIKA DI SMA
}

\author{
Sahlan $^{1}$, Widodo ${ }^{2}$, Ishafit ${ }^{3}$ \\ ${ }^{1}$ IKIP Muhammadiyah Maumere, ${ }^{2,3}$ Universitas Ahmad Dahlan Yogyakarta \\ e-mail : syahlanfairuz@gmail.com
}

\begin{abstract}
The Effect of Phyphox-Assisted Experiential Learning Model on Motivation to Learn Physics in High School. The purpose of this study was to determine the significant difference between students who took part in learning using the experiential learning model assisted by the phyphox application and students who took part in learning using the experiential learning model without the aid of the phyphox application on learning motivation. This research uses quantitative research methods with a true experimental design approach. The research design used is a pre-test-post-test control group design in which there is a control class and an experimental class. Test results using One-Way Anova assisted by SPSS. 25, obtained a significant value of $0.000<0.05$ (Fcount > Ftable; 7,708 > 4.24). In addition, a simple linear regression test was obtained explaining the magnitude of the correlation value or $R$ value relationship of 0.854 and obtained $R$ Square of 0.729, which implies that the effect of the experiential learning model assisted by the phyphox application on learning motivation is 72.9\%. So it can be concluded that there is a significant difference between students who are taught using the experiential learning model assisted by the phyphox application and students who are taught using the experiential learning model without the aid of the phyphox application.
\end{abstract}

Keywords: Experiential Learning, Aplikasi Phyphox, Motivation.

\begin{abstract}
Abstrak: Pengaruh Model Experiential Learning Berbantuan Phyphox Terhadap Motivasi Belajar Fisika Di SMA. Tujuan dalam penelitian ini untuk mengetahui perbedaan yang signifikan antara peserta didik yang mengikuti pembelajaran dengan menggunakan model experiential learning berbantuan aplikasi phyphox dan peserta didik yang mengikuti pembelajaran dengan menggunakan model experiential learning tanpa bantuan aplikasi phyphox terhadap motivasi belajar. Penelitian ini menggunakan metode penelitian kuantitatif dengan pendekatan true experimental design. Desain penelitian yang digunakan adalah pre test-post test control group design didalamnya terdapat kelas kontrol dan kelas eksperimen. Hasil uji menggunakan One-Way Anova berbantuan SPSS. 25, diperoleh nilai signifikan $0,000<0,05$ (nilai $\mathrm{F}_{\text {hitung }}>\mathrm{F}_{\text {tabel }}$; $7,708>4,24)$. Selain itu, diperoleh uji regresi linear sederhana menjelaskan besarnya nilai korelasi atau hubungan nilai $\mathrm{R}$ sebesar 0,854 dan diperoleh $\mathrm{R}$ Square 0,729, yg mengandung pengertian bahwa pengaruh model eksperiential learning berbantuan aplikasi phyphox terhadap motivasi belajar adalah sebesar
\end{abstract}


72,9\%. Sehingga dapat disimpulkan bahwa terdapat perbedaan yang signifikan antara siswa yang diajar dengan menggunakan model experiential learning berbantuan aplikasi phyphox dengan peserta didik yang diajar dengan menggunakan model experiential learning tanpa bantuan aplikasi phyphox.

Kata kunci: eksperiential learning, aplikasi phyphox, motivasi

\section{PENDAHULUAN}

Perkembangan pengetahuan dan teknologi sangat pesat seiring berjalannya waktu. Persaingan ketat antara bangsa semakin terlihat pada era ini. Revolusi industri 4.0 ditandai dengan peningkatan teknologi informasi, internet data dan artificial intelligence memotivasi bangsa untuk meningkatkatkan ilmu pengetahuan dan teknologi. Masalah pendidikan memegang peranan penting dalam perkembangan ilmu pengetahuan dan teknologi suatu bangsa. Bangsa yang besar tentunya harus memiliki sumber daya manusia yang mampu mengikuti perkembangan ilmu pengetahuan dan teknologi dunia, tentunya ini menjadi tanggung jawab pemerintah sebagaimana tercantum dalam pembukaan UUD 1945.

Pendidikan di Indonesia masih sangat jauh dari kata berhasil sebagaimana yang diharapkan dalam Undang-Undang No.20 Tahun 2003. Penyebab utamanya terdapat pada hal-hal teknis dalam proses pembelajaran yang belum sepenuhnya dilakukan serta kelengkapan sarana prasarana. Inti dari permasalahan yang dihadapi adalah pendekatan dan metode yang digunakan dalam proses pembelajaran yang kurang sesuai. Kegiatan belajar mengajar yang masih bersifat monoton dan pasif sehingga mempengaruhi rendahnya kualitas pendidikan di Indonesia. Kegiatan belajar mengajar tidaklah terlepas dari peran serta guru. Guru diharapkan menjadi sosok yang mampu hadir sebagai fasilitator dan motivator pembelajaran.

Fisika sampai saat ini menjadi salah satu pelajaran yang dianggap sukar oleh peserta didik, ini menjadi permasalahan yang harus dicarikan solusi bersama baik pemerintah, guru dan masyarakat. Pemahaman konsep dan hasil belajar fisika khususnya pada tingkatan SMA masih sangat rendah, faktor penyebabnya karena desain pendidikan yang ditampilkan kurang sesuai dengan hakikat belajar dan mengajar fisika (Santyasa, 2005).

Fisika merupakan bagian dari sains yaitu ilmu pengetahuan alam yang menjelaskan fenomena yang dapat diamati (observable) dengan model-model (P Suwindra, 2017). Fisika merupakan bagian dari kelompok mata pelajaran IPA yang mencakup pengetahuan berupa fakta, teori, prinsip dan hukum berdasarkan temuantemuan saintis dan kerja ilmiah. Fisika juga merupakan salah satu ilmu dasar yang dikembangkan berdasarkan pengamatan fenomena fisik pada alam yang sering dijumpai dalam kehidupan sehari-hari, sehingga pada prinsipnya belajar fisika adalah mempelajari tentang alam (Johari \& Muslim, 2018). Belajar fisika merupakan tuntutan yang harus dilalui siswa di sekolah khusnya di tingkat SMA.

Menurut Rahyubi belajar merupakan proses yang harus dilalui dalam hidup setiap manusia untuk mencapai berbagai macam kompetensi, pengetahuan dan keterampilan dan sikap (Rahyubi, 2014). Dengan demikian, tentunya belajar menjadi kewajiban yang harus dimiliki setiap orang mengingat begitu pentingnya didukung dengan pendapat Hilgrad dan Bower dalam (Rahyubi, 2014) belajar adalah memperoleh pengetahuan atau menguasai pengetahuan melalui pengalaman, mengingat, menguasai pengalaman, dan mendapatkan informasi atau menemukan. Kegiatan belajar tentunya harus didukung dengan motivasi yang tinggi agar lebih mudah memahami sesuatu yang dipelajari.

Sudjana berpendapat bahwa motivasi siswa dapat dilihat dari beberapa hal, antara lain: (Sudjana, 2016). 1) Minat dan perhatian siswa terhadap pelajaran; 2) Semangat siswa untuk melakukan tugas-tugas belajarnya; 3) Tanggungjawab siswa dalam mengerjakan tugas-tugas belajarnya; 4) Reaksi yang ditunjukkan siswa terhadap stimulus yang diberikan guru; 5) Rasa senang dan puas dalam mengerjakan tugas yang diberikan “. Selain 
motivasi yang dibutuhkan dalam belajar siswa, ada faktor-faktor lain yang menjadi pendukung dalam kegiatan belajar khususnya di sekolah. Salah satu faktor yang mendukung kegiatan belajar adalah penggunaan model pembelajaran yang digunakan guru di kelas.

Mahfuddin dalam Majid (2014) menjelaskan bahwa model experiential learning merupakan tindakan untuk mencapai sesuatu berdasarkan pengalaman yang secara berkelanjutan guna meningkatkan keefektifan dari hasil belajar (Majid, A., Rochman, 2014). Siklus penerapan model experiential learning oleh Kolb tertera pada Gambar 1: (Kolb Y \& Kolb A, 2016).

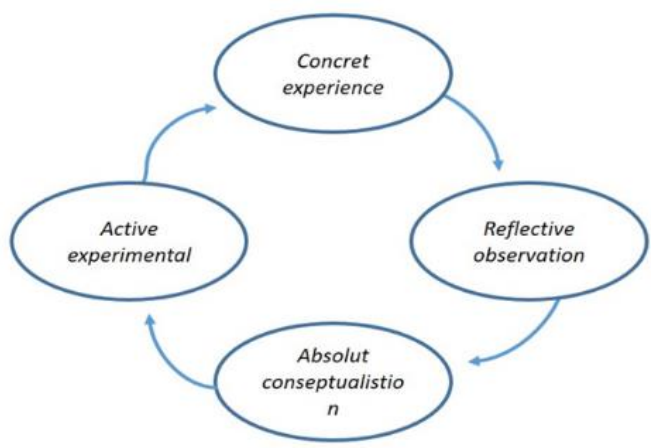

Gambar 1. Kolb's Experiential Learning Cycle

Pada tahapan yang ditampilkan dalam Gambar 1 adalah proses penerapan model experiential learning dimulai dari pengalaman konkret yang alami oleh siswa. Pengalaman tersebut kemudian direfleksikan, sehingga siswa berusaha memahami apa yang terjadi. Perkembangan teknologi saat ini khususnya pada alat komunikasi seperti smartphone dilengkapi sistem android didukung dengan banyaknya aplikasi-aplikasi yang dapat dimanfaatkan untuk media pembelajaran dalam proses KBM di kelas. Aplikasi yang dapat digunakan secara gratis serta dapat membantu proses KBM di kelas khususnya pada pembelajaran fisika adalah aplikasi phyphox.

Phyphox adalah aplikasi eksperimen fisika dilengkapi sensor pada smartphone. Aplikasi phyphox (physical phone experiments) pertama dirilis dalam Google's Play Store and Apple's App Store pada September 2016 (Staacks, Hütz, Heinke, \& Stampfer, 2018). Aplikasi ini dapat diaktifkan dari android atau tablet. Pembacaan data bisa bermasalah jika layarnya tidak terlihat karena perangkat ini pasti ditempatkan di tempat objek yang bergerak, sehingga disediakan mode mirroring ("remote akses") langsung di komputer/PC (Sahlan, Ishafit, Fayanto, 2019).

Aplikasi phyphox memberi kemudahan dengan tersedianya aplikasi yang dapat diakses langsung ke sensor. Selain itu, tersedia berbagai bidang seperti akustik, mekanik, kronometer, dll (lihat Gambar 2).

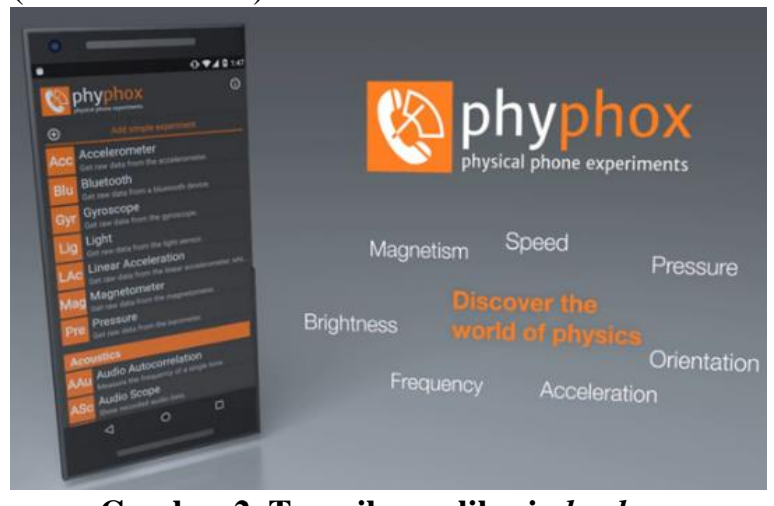

Gambar 2. Tampilan aplikasi phyphox

Peneliti menemukan dilapangan bahwa ternyata pembelajaran fisika dikelas masih kurang efektif. Hal ini dikarenakan kurangnya kompetensi guru fisika memanfaatkan teknologi dalam proses pembelajaran sehingga proses pembelajaran menjadi monoton dan pasif, akibatnya siswa menjadi malas belajar (Wijanarko, 2017).

Dari uraian teori dan fakta yang diuraikan diatas sehingga peneliti menganalisis pengaruh penggunaan model pembelajaran experiential learning berbantuan aplikasi Phyphox terhadap motivasi belajar siswa di SMA.

\section{METODE}

Penenlitian ini menggunakan metode penelitian kuantitatif dengan pendekatan true experimental design. Desain penelitian yang digunakan adalah pre test-post test control group design didalamnya terdapat kelas kontrol dan kelas eksperimen. Tujuan dalam penelitian ini untuk mengetahui perbedaan yang signifikan antara peserta didik yang mengikuti pembelajaran dengan menggunakan model experiential learning berbantuan aplikasi phyphox dan peserta didik yang mengikuti pembelajaran dengan menggunakan model experiential learning tanpa bantuan aplikasi phyphox terhadap motivasi belajar. 
Karst : Jurnal Pendidikan Fisika dan Terapannya Volume 4 | Nomor 2 | 79

p-ISSN: 2622-9641 e-ISSN: 2655-1276

Populasi dalam penelitian ini adalah seluruh kelas X MIPA SMA Muhammadiyah Maumere dengan jumlah siswa sebanyak 105 peserta didik terdiri 4 rombel. Sampel penelitian 40 orang dari 2 rombel, terdiri dari 20 orang di kelas kontrol dan 20 orang di kelas eksperimen. Teknik pengambilan sampel menggunakan cluster random sampling yang didasari karena dalam proses pelaksanaannya tidak dapat mengambil sampel secara individu dan dengan kondisi peserta didik yang memiliki latarbelakang dan kemampuan yang homogen.

Instrumen yang digunakan dalam penelitian adalah angket motivasi. Angket yang digunakan dalam penelitian ini berupa angket tertutup. Penelitian ini menggunakan angket pada tinjauan skala likert dengan empat pilihan jawaban yaitu sangat setuju, setuju, tidak setuju dan sangat tidak setuju (Sugiyono, 2018).

Angket ini mengadopsi dari pendapat Hamzah yang membagi indikator motivasi menjadi 6 aspek. Aspek motivasi meliputi aspek Adanya hasrat dan keinginan berhasil, Adanya dorongan dan kebutuhan belajar, Adanya harapan dan cita-cita masa depan,
Adanya penghargaan dalam belajar, Adanya kegiatan yang menarik dalam belajar, Adanya lingkungan belajar yang kondusif (Hamzah B. U, 2011).

Data sebelum dianalisis dengan uji anova terlebih dahulu dilakukan uji normalitas menggunakan one sample Kolmogorov-smirnov test. Teknik analisis data yang digunakan dalam penelitian ini adalah menggunakan uji Anova berbantuan SPSS. 25. Uji anova digunakan untuk mengetahui adakah pengaruh variabel bebas model pembelajaran experiential learning berbantuan aplikasi phyphox dan model experiential learning tanpa bantuan aplikasi phyphox terhadap motivasi belajar.

\section{HASIL DAN PEMBAHASAN}

Analisis deskriptif motivasi belajar siswa diukur melalui kusioner dilakukan sebelum dan sesudah tindakan pada kelas eksperimen dengan menggunakan model pembelajaran experiential learning berbantuan phyphox dan kelas kontrol menggunakan model experiential learning tanpa berbantuan phyphox.

Hasil analisis deskriptif motivasi belajar siswa ditampilkan pada Tabel 1.

Tabel 1. Pengkategorian indikator motivasi belajar kelas kontrol dan kelas eksperimen

\begin{tabular}{lcc}
\hline \multicolumn{1}{c}{ Indikator } & Kelas eksperimen (\%) & Kelas kontrol (\%) \\
\hline Adanya hasrat dan keinginan berhasil & 71 & 70 \\
Adanya dorongan dan kebutuhan belajar & 73 & 72 \\
Adanya harapan dan cita-cita masa depan & 71 & 71 \\
Adanya penghargaan dalam belajar & 73 & 71 \\
Adanya kegiatan yang menarik dalam belajar & 73 & 72 \\
Adanya lingkungan belajar yang kondusif & 75 & 71 \\
\hline Berdasarkan Tabel 1 terlihat bahwa masing- & angket siswa kurang serius dalam mengisi \\
masing indikator tidak menunjukkan perbedaan & angket yang dibagikan peneliti. Sehingga kami \\
nilai yang cukup tinggi, sehingga dapat & berharap peneliti selanjutnya dapat melanjutkan \\
disimpulkan bahwa tidak terjadi perbedaan yang & penelitian ini dengan memperhatikan \\
signifikan dikerenakan dalam pengambilan data & kekurangan yang dimaksud.
\end{tabular}

Tabel 2. Signifikansi nilai $\mathrm{N}$-gain motivasi belajar pada kelas eksperimen dan kelas kontrol.

\begin{tabular}{|c|c|}
\hline \multicolumn{2}{|c|}{ Nilai $N$-Gain } \\
\hline Kelas eksperimen & Kelas kontrol \\
\hline 0,3 & 0,20 \\
\hline $\begin{array}{l}\text { Dari Tabel } 2 \text { menjelaskan bahwa terdapat } \\
\text { perbedaan nilai signifikansi motivasi belajar } \\
\text { antara kelas eksperimen dan kelas kontrol. Hal } \\
\text { ini terlihat dari nilai } N \text {-gain untuk kelas } \\
\text { eksperimen sebesar } 0,3 \text { dan kelas kontrol sebesar }\end{array}$ & $\begin{array}{l}\text { 0,2. Sehingga dapat disimpulkan bahwa pada } \\
\text { kelas eksperimen peningkatan nilai signifikansi } \\
\text { berada pada kategori sedang, sedangkan kelas } \\
\text { kontrol berada pada kategori rendah. Hal ini } \\
\text { dikarenakan rentang skala kategori sedang }\end{array}$ \\
\hline
\end{tabular}


Karst : Jurnal Pendidikan Fisika dan Terapannya

Volume 4 | Nomor 2 | 80

p-ISSN: 2622-9641 e-ISSN: 2655-1276

adalah $0,3 \geq \mathrm{g} \leq 0,7$ dan kategori rendah nilai $N$ gain berada pada skala $\mathrm{g}<0,3$.

Berdasarkan hasil uji normalitas menjelaskan bahwa data pretest dan posttest untuk kelas eksperimen yaitu kelas yang menerapkan pembelajaran dengan model experiential learning berbantuan aplikasi phyphox atau kelas kontrol yang tanpa berbantuan aplikasi phyphox memiliki data yang terdisitribusi normal

Tabel 3. Hasil Uji Anova model pembelajaran terhadap motivasi belajar

\begin{tabular}{ccccccc}
\multicolumn{8}{c}{ ANOVA $^{\boldsymbol{a}}$} \\
\hline Model & & Sum of Squares & $d f$ & Mean Square & F & Sig. \\
\hline \multirow{4}{*}{1} & Regression & 1144.900 & 1 & 1144.900 & 102.440 & $.000^{\mathrm{b}}$ \\
& Residual & 424.700 & 38 & 11.176 & & \\
& Total & 1569.600 & 39 & & & \\
\hline
\end{tabular}

a. Dependent Variable: motivasi belajar

b. Predictors: (Constant), model pembelajaran

Tabel 4. Hasil Uji Regresi Linear Sederhana

\begin{tabular}{ccccc}
\multicolumn{5}{c}{ Model Summary $^{b}$} \\
\hline Model & $R$ & $R$ Square & Adjusted $R$ Square Std. Error of the Estimate \\
\hline 1 & $.854^{\mathrm{a}}$ & .729 & .722 & 3.343 \\
\hline
\end{tabular}

Berdasarkan Tabel 3 menggunakan uji One-Way Anova berbantuan SPSS 25, diperoleh nilai signifikan $0,000<0,05$ (nilai $F_{\text {hitung }}>F_{\text {tabel }}$; $102,4>4,35$ ). Selain itu, diperoleh uji regresi linear sederhana menjelaskan besarnya nilai korelasi atau hubungan nilai $\mathrm{R}$ sebesar 0,854 dan diperoleh R Square 0,729 (lihat Tabel 4) yg mengandung pengertian bahwa pengaruh model eksperiential learning berbantuan aplikasi phyphox terhadap motivasi belajar adalah sebesar $72,9 \%$.

Sehingga dapat disimpulkan bahwa terdapat perbedaan yang signifikan antara siswa yang diajar dengan menggunakan model experiential learning berbantuan aplikasi phyphox dengan peserta didik yang diajar dengan menggunakan model experiential learning tanpa bantuan aplikasi phyphox.

\section{PEMBAHASAN}

Berdasarkan hasil analisis deskriptif motivasi belajar siswa bahwa terdapat perbedaan nilai rata-rata pretest dan posttest antara peserta didik yang diajar dengan menggunakan model pembelajaran experiential learning berbantuan aplikasi phyphox dengan peserta didik yang diajar dengan model experiential learning tanpa bantuan aplikasi phyphox. Data ini kemudian diperkuat dengan hasil uji anova berbantuan SPSS 25 diperoleh hasil analisis bahwa nilai signifikansi 0,000<0,05 (Fhitung > Ftabel ; $102,4>4,35)$.

Hasil yang diperoleh tersebut dapat disimpulkan bahwa terdapat perbedaan yang signifikan antara siswa yang diajar dengan menggunakan model experiential learning berbantuan aplikasi phyphox dengan peserta didik yang diajar dengan menggunakan model experiential learning tanpa bantuan aplikasi phyphox. Hal ini sesuai dengan penelitian (Wayan, Lestari, Sadia, \& Suma, 2014) bahwa terdapat perbedaan kemampuan keterampilan berpikir kritis dan motivasi berprestasi antara siswa yang belajar dengan model pembelajaran experiential learning dengan siswa yang belajar dengan model pembelajaran konvensional.

Penelitian ini diperkuat dengan hasil yang diperoleh pada persentase tingkat pengaruh penggunaan model pembelajaran experiential learning berbantuan aplikasi phyphox terhadap motivasi siswa sebesar $72,9 \%$ seperti yang ditampilkan pada Tabel 4. Disimpulkan bahwa ternyata siswa yang diajar menggunakan model pembelajaran experiential learning berbantuan aplikasi phyphox dapat membantu meningkatkan motivasi siswa dalam mengikuti pembelajran fisika di kelas. 
Hal ini didukung dengan penelitian yang dilakukan oleh Wahyuningsih (2014) menyebutkan bahwa pembelajaran fisika dengan menggunakan model experiential learning berdampak pada motivasi belajar dalam kriteria "termotivasi" pada siswa SMK (Wahyuningsih Dwi, Indrawati, 2014). Selanjutnya, dipertegas kembali oleh Giudice dalam penelitiannya menyebutkan bahwa penerapan aplikasi phyhpox dalam pembelajaran mampu meningkatkan motivasi siswa (Giudice, 2018).

Berdasarkan dukungan dari beberapa teori diatas dan hasil penelitian yang kami peroleh sehingga dapat kami simpulkan bahwa pembelajaran menggunakan model experiential learning berbantuan aplikasi phyphox dalam pembelajaran fisika di sekolah dapat meningkatkan motivasi belajar siswa.

\section{PENUTUP}

Berdasarkan hasil dan pembahasan diatas, sehingga dapat disimpulkan bahwa terdapat pengaruh yang signifikan antara siswa yang diajar menggunakan model pembelajaran experiential learning berbantuan aplikasi phyphox dapat meningkatkan motivasi belajar fisika siswa.

Hal ini didukung dengan penelitian oleh Zuhryzal menyebutkan bahwa penerapan model experiential learning efektif terhadap motivasi dan hasil belajar IPA siswa (Setyaningsih, Benardi, Aji, \& Kahfi, 2019).

Dari perhitungan yang dilakukan dengan menggunakan uji Anova berbantuan SPSS. 25 diperoleh hasil bahwa terdapat pengaruh yang signifikan terhadap motivasi belajar antara siswa yang diajar dengan menggunakan model experiential learning berbantuan aplikasi phyphox dibandingkan siswa yang diajar dengan menggunakan model experiential learning tanpa bantuan aplikasi phyphox. Didukung dengan penelitian yang dilakukan oleh Giuliana Lo Giudice bahwa Smartphone (aplikasi phyphox) dapat digunakan untuk mengajar, mengubah ruang kelas tradisional menjadi laboratorium sains dan fisika dan merangsang rasa ingin tahu terhadap siswa dalam melakukan eksperimen (Giudice, 2018).
Jadi model pembelajaran eksperiential learning berbantuan aplikasi phyphox yang diterapkan dalam kegiatan pembelajaran dapat menjadi acuan untuk para pendidik dalam melaksanakan kegiatan pembelajaran, dengan tujuan khusus untuk menumbuhkan serta meningkatkan motivasi belajar siswa pada pembelajaran fisika.

Tindak lanjut dari penelitian ini adalah upaya meningkatkan motivasi belajar siswa SMA terhadap pembelajaran fisika dengan penerapan model pembelajaran experiential learning dapat ditingkatkan. Rencana tindak lanjut penerapan model pembelajaran eksperiential learning berbantuan aplikasi phyphox tidak hanya sebatas meningkatkan motivasi siswa saja, namun akan diterapkan pada siswa agar materi fisika yang diberikan oleh guru mudah diterima oleh siswa karena model pembelajaran experiential learning berbantuan aplikasi phyphox berdasarkan pada pengalaman siswa sehingga memacu ingatan siswa lebih cepat, akibatnya siswa lebih mudah mengingat serta mampu memahami materi fisika tersebut dengan baik.

\section{DAFTAR PUSTAKA}

GiudiJoharice, G. Lo. 2018. Davvero prof prendiamo i nostri cellulari ? Fisica in Mobile Learning.

Hamzah B. U. 2011. Teori Motivasi dan Pengukurannya: Analisis di Bidang Pendidikan. Jakarta: Bumi Aksara.

Johari, A. H., \& Muslim. 2018. Application of experiential learning model using simple physical kit to increase attitude toward physics student senior high school in fluid. Journal of Physics: Conference Series, 1013(1). https://doi.org/10.1088/17426596/1013/1/012032

Kolb Y, A., \& Kolb A, D. 2016. Learning Styles and Learning Spaces: Enhancing Experiential Learning in Higher Education. Academy of Management Learning \& Education, 4(2), 193-212. https://doi.org/10.5465/AMLE.2005.17268566

Majid, A., Rochman, C. 2014. Pendekatan Ilmiah Dalam Implementasi Kurikulum 2013. Bandung: Rosda Karya.

P Suwindra, I. N. 2017. Pengembangan Modul Software Multimedia Interaktif Dengan Strategi Pembelajaran Berbasis Masalah Untuk Meningkatkan Pemahaman Konsep Dan Hasil Belajar Fisika Siswa Kelas XII 
Karst : Jurnal Pendidikan Fisika dan Terapannya Volume 4 | Nomor 2 | 82 p-ISSN: 2622-9641 e-ISSN: 2655-1276

SMA. JPI (Jurnal Pendidikan Indonesia), 1(1). https://doi.org/10.23887/jpiundiksha.v1i1.4483

Rahyubi, H. 2014. Teori-Teori Belajar Dan Aplikasi Pembelajaran Motorik: Deskripsi dan Tinjauan Kritis. Jawa Barat: Referens.

Sahlan, Ishafit, Fayanto, S. 2019. Theoretical and experimental studies on centripetal acceleration using the Phyphox application. International Journal of Scientific and Research Publications (IJSRP), 9(9), p9322. https://doi.org/10.29322/ijsrp.9.09.2019.p9322

Santyasa, I. W. 2005. Model Pembelajaran Inovatif dalam Implementasi Kurikulum Berbasis Kompetensi. Denpasar: FMIPA IKIP Negeri Singaraja.

Setyaningsih, W., Benardi, A. I., Aji, A., \& Kahfi, A. 2019. Indonesian Journal of Conservation. Indonesian Journal of Conservation, 3(1), 99110. Retrieved from https://journal.unnes.ac.id/nju/index.php/ijc/art icle/view/3085
Staacks, S., Hütz, S., Heinke, H., \& Stampfer, C. 2018. Advanced tools for smartphone-based experiments: Phyphox. Physics Education, 53(4), 1-8. https://doi.org/10.1088/1361$6552 / \mathrm{aac} 05 \mathrm{e}$

Sudjana, N. 2016. Penilaian Hasil Proses Belajar Mengajar. Bandung: Rosdi Karya.

Sugiyono. 2018. Metode Penelitian kuantitatif, Kualitatif dan R\&D. Bandung: Alfabeta.

Wahyuningsih Dwi, Indrawati, W. S. 2014. Motivasi belajar dan pemahaman konsep fisika siswa smk dalam pembelajaran menggunakan model. Jurnal Pembelajaran Fisika.

Wayan, N., Lestari, R., Sadia, I. W., \& Suma, K. 2014. Terhadap Keterampilan Berpikir Kritis Dan Motivasi Berprestasi Siswa Universitas PendidikanGanesha e-Journal Program Pascasarjana Universitas Pendidikan Ganesha. 4.

Wijanarko, J. 2017. Memaksimalkan Otak Anak Anda. Jakarta Selatan: Keluarga Indah Bahagia. 